\title{
The effect of the drug Atlante Plus on the formation of the solanum lycopersicum $L$. crop in the central zone of the Krasnodar Territory
}

\author{
Natalya Varfolomeyeva*, Elena Blagorodova, and Tamara Nepshekueva \\ Kuban State Agrarian University, 350044, 13, Kalinin str., Krasnodar, Russian Federation
}

\begin{abstract}
Physiologically active substances play an important role in the formation of the vegetable crops harvest, influencing the timing of product receipt, its size and quality. In the Krasnodar Territory, the leading place among vegetable crops in the open ground is occupied by solanum lycopersicum L., the crop stability of which is complicated by high temperatures and insolation during the growing season. Using the drug Atlante Plus makes it possible to increase the stress resistance of plants, provide the necessary phosphorus-potassium nutrition. Studies conducted in 2021 in the central zone of the Krasnodar Territory revealed the drug effectiveness for pre-sowing seed preparation and spraying of solanum lycopersicum L. plantings during budding. Soaking seeds in the drug solution with the concentration of $0.005 \%$ increased their germination energy and laboratory germination, activated growth processes in seedlings. Spraying of vegetat-ing plants with a solution of the same concentration increased the leaf surface area by $28 \mathrm{~cm}^{2}$, and the productivity of one plant - by $180 \mathrm{~g}$.
\end{abstract}

\section{Introduction}

The importance of vegetables as a source of natural antioxidants is constantly increasing in the system of healthy nutrition. There is a dynamic growth in the production of vegetable products in the world, which is a consequence of state programs effective implementation in different countries.

Vegetable crops are indispensable in the diet and have a positive impact on the health, efficiency and life expectancy of people. The Solanaceae family, which includes not only grasses and shrubs, but even trees, includes more than 2.300 plant species.

Representatives of this family are the most widespread food products in the modern world, an important component of a full-fledged human nutrition and they provide support for vital forces. Solanum lycopersicum L. is an agricultural crop, also used for medical and decorative purposes. This vegetable crop occupies the fifth place in the world in terms of food products importance after triticum aestivum L., Solanum tuberosum L., Zea maus L. and Oryza sativa L.) $[1,2]$.

\footnotetext{
*Corresponding author: varfolomeeva_ni@mail.ru
} 
In the industrial sector of vegetable growing in Russia, according to the agribusiness expert-analytical center data, the Krasnodar Territory accounts for 33.3 thousand hectares, which is $17.7 \%$ in the ranking of the TOP-5 regions in terms of the open ground areas size occupied by vegetable crops. In 2019 and 2020, the open ground vegetable production volumes in the Krasnodar Territory (Russia) amounted to 188.7 and 188.5 thousand tons, respectively. In comparison with 2018 , the area occupied by vegetables increased by $5 \%$, and is 1.6 thousand hectares.

In Russia in 2019, the open ground acreage of solanum lycopersicum L. in farms of all categories amounted to 82.4 thousand hectares, which is 0.7 thousand hectares less than in 2018, and 0.8 thousand hectares more than in 2020. The sown areas of solanum lycopersicum L. in private subsidiary farms in Russia amounted to 64.6 thousand hectares on average for 2019-2020. Compared to 2018, they decreased by 2.18 thousand hectares. The Krasnodar Territory took the 6th place in the general rating for solanum lycopersicum L. gross harvest in the open ground in 2019-2020, and the yield of the crop from the area of 0.6 thousand ha amounted to 17.3 thousand tons. For 2019-2020, the gross harvest of solanum lycopersicum L. open ground industrial cultivation in Russia increased by 49.2 thousand tons compared to $2018[3,4]$.

According to the experts of the Institute of Agricultural Market Conjuncture, solanum lycopersicum L. is the leader in the ranking of the most consumed vegetables in the world, which is explained by the medical need per capita, which is approximately $80.5-89.3 \mathrm{~kg}$ of fruits. For example, in Germany, France, the United States, this vegetable is 2 times more, and in Italy-4 times more consumed [1, 4].

It should be noted that the demand for vegetable products increases annually, especially for solanum tuberosum L., solanum lycopersicum L., capsicum annuum L., solanum melongena L. For the cultivation of light-loving and heat-resistant vegetable plants of the Solanaceae family, the conditions of the Krasnodar Territory are very favorable.

When growing vegetable crops, agricultural producers regularly face the problem of a shortage of trace elements forms available for plants in the soil, which, as a result, leads to the decrease in yield and product quality. One of the most important reserves for obtaining consistently high solanum lycopersicum L. yields is the scientifically based physiologically active compounds application that affect the process of plants development, increase their yield and fruit quality [5-8].

Currently, significant factual material has been accumulated that highlights the effect of physiologically active substances on plants. These substances are used in agriculture to accelerate the emergence of plant seedlings (to reduce seed germination period), stimulate the process of root formation in cuttings, bulbs; accelerate the growth of the root system in transplanted plants, to increase productivity and improve the quality of vegetable and flower products [9-11].

One of these new generation physiologically active substances is the phosphoruspotassium fertilizer Atlante Plus. The drug is a modern antimycotic. This is a phosphoruspotassium fertilizer containing salicylic acid and betaines, which stop the processes providing the main vital functions of the fungal cell that affects the plant. The result of the Atlante Plus fertilizer impact is the increase in the yield and quality of the products obtained. However, despite the identification of this drug properties, there is insufficient information about its regulatory effect on representatives of the Solanaceae family in the soil and climatic conditions of the Kuban.

The aim of this work is to study the influence of the physiologically active substance Atlante Plus on the sowing qualities of seeds, growth processes and crop formation of solanum lycopersicum L. in the conditions of the central zone of the Krasnodar Territory. 


\section{Methods}

The research was conducted in 2021 in the field experiment conditions. The soil is leached heavy - duty chernozem, according to the main indicators suitable for growing solanum lycopersicum L. The area of the accounting plot is $10 \mathrm{~m}^{2}$, the location of the plots is tiered, systematic, the experiment repetition is threefold. The object of the study was the hybrid of solanum lycopersicum L. TMAE $683 \mathrm{~F}_{1}$.
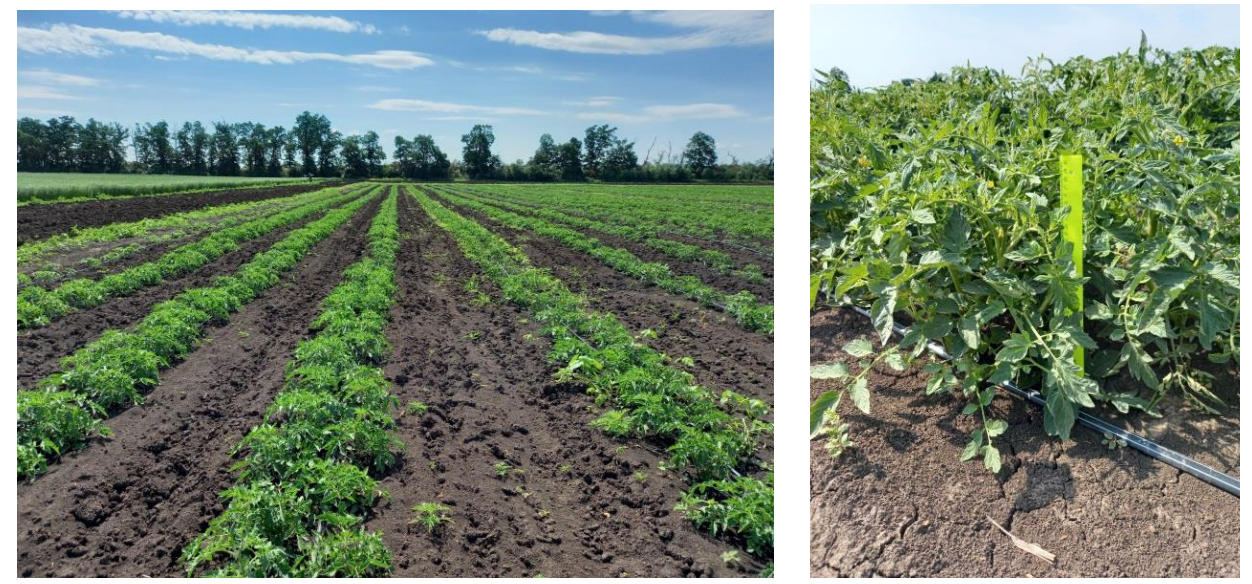

Fig. 1. The hybrid solanum lycopersicum L. TMAE $683 \mathrm{~F}_{1}$.

The hybrid solanum lycopersicum L. TMAE $683 \mathrm{~F}_{1}$ is the selection of Sakata company. Large-fruited, salad it is designed for open ground and film greenhouses. The hybrid is characterized by precocity, the growing season is up to 95 days. The plant is of a determinant type, semi-spreading, medium-branched, medium-leaved. Dense fruits with a bright color, high dry matter content, weighing up to $190 \mathrm{~g}$ are suitable for preparing fresh salads, natural juices. The variety is resistant to fusarium, verticillosis.

When growing seedlings of solanum lycopersicum L., plastic cassettes filled with a peat substrate were used.

The experiment was conducted in two stages:

1. The vegetation experiment was carried out in the conditions of greenhouse production. It included 3 options (soaking the seeds):

Option 1. Control-water;

Option 2. Atlante Plus, $0.001 \%$ solution;

Option 3. Atlante Plus, $0.005 \%$ solution.

In accordance with generally accepted methods, the seeds of solanum lycopersicum L. were soaked before sowing for 3 hours. Germination energy was determined on the 5 th day, laboratory germination - on the 10th day.

2. The field experiment included 3 variants (spraying of vegetating solanum lycopersicum L. plants in the budding phase):

Option 1. Control-water;

Option 2. Atlante Plus, $0.001 \%$ solution;

Option 3. Atlante Plus, $0.005 \%$ solution.

The laying of field experience, laboratory studies, phenological and biometric observations were carried out according to generally accepted methods.

The obtained data were processed by the method of variance analysis according to B. A. Dospekhov [12]. 


\section{Results}

In the last decade, scientists in a number of research institutions in different countries have conducted extensive research on new ways to use well-known physiologically active substances that contribute to raising yields and improving various crops quality. According to published sources, many growth stimulators have not found wide application in agricultural practice, due to the fact that they are understudied or high cost.

Numerous studies have proved that plants reaction to the growth stimulators action is determined by many factors, varietal and species characteristics of plants, as well as the conditions of their growth are among them. The initial changes occurring in seeds after their processing lead to phenomena associated with an increase in the metabolism intensity in their cells. These processes are carried out at the early stages of plant development during the period of their greatest plasticity and susceptibility, and can have a decisive influence on the later development stages of an adult organism. Studies have found that presowing soaking seeds in solutions of growth regulators leads to a significant increase in their sowing qualities - germination energy and laboratory germination

The use of the preparation Atlante Plus solution for soaking solanum lycopersicum L. seeds increased their sowing qualities and somewhat stimulated the growth processes in seedlings (Table 1).

Table 1. The effect of the Atlante Plus drug on the seeds sowing qualities and solanum lycopersicum L. seedlings growth processes, 2021 (sowing on March 29).

\begin{tabular}{|c|c|c|c|c|c|c|}
\hline \multirow[b]{2}{*}{$\begin{array}{l}\text { Option } \\
\text { (seed } \\
\text { treatment) }\end{array}$} & \multicolumn{4}{|c|}{ Phenological phase occurrence date } & \multirow[b]{2}{*}{$\begin{array}{c}\text { Germinati } \\
\text { on energy, } \\
\%\end{array}$} & \multirow[b]{2}{*}{$\begin{array}{c}\text { Laborator } \\
\mathbf{y} \\
\text { germinati } \\
\text { on, } \%\end{array}$} \\
\hline & $\begin{array}{c}\text { single } \\
\text { shoot } \\
\text { s }\end{array}$ & $\begin{array}{c}\text { mass } \\
\text { shoots }\end{array}$ & $\begin{array}{c}\text { the } \\
\text { appearance } \\
\text { of } 1 \text { real } \\
\text { sheet }\end{array}$ & $\begin{array}{c}2-3 \\
\text { real } \\
\text { leaves }\end{array}$ & & \\
\hline $\begin{array}{l}\text { Control, } \\
\text { water }\end{array}$ & 06.04 & 09.04 & 26.04. & 02.05 & 86,9 & 91,1 \\
\hline $\begin{array}{l}\text { Atlante Plus } \\
(0,001 \% \\
\text { solution) } \\
\end{array}$ & 06.04 & 09.04 & 24.04. & 30.04 & 90,6 & 93,4 \\
\hline $\begin{array}{l}\text { Atlante Plus } \\
(0,005 \% \\
\text { solution) }\end{array}$ & 05.04 & 08.04 & 23.04 & 29.04 & 92,4 & 95,9 \\
\hline $\mathrm{LSD}_{05}$ & & & & & 2,0 & 2,5 \\
\hline
\end{tabular}

During the field experiment, plantings spraying with solanum lycopersicum L. with a solution of the physiologically active substance Atlante Plus at the experimental site during the budding phase affected the plants growth and development processes (Table 2).

Table 2. The effect of the drug Atlante Plus on solanum lycopersicum L. plant productivity, 2021.

\begin{tabular}{|c|c|c|c|c|c|}
\hline \multirow{2}{*}{$\begin{array}{c}\text { Option (spraying } \\
\text { of vegetating } \\
\text { plants) }\end{array}$} & \multirow{2}{*}{$\begin{array}{c}\text { The } \\
\text { onset of } \\
\text { the } \\
\text { flowerin } \\
\text { g phase }\end{array}$} & \multirow{2}{*}{$\begin{array}{l}\text { Leaf } \\
\text { surface } \\
\text { area, } \\
\text { cm }^{2}\end{array}$} & \multirow{2}{*}{$\begin{array}{l}\text { The } \\
\text { number of } \\
\text { fruits per } \\
\text { plant, pes. }\end{array}$} & \multicolumn{2}{|c|}{$\begin{array}{l}\text { Weight of fruits } \\
\text { from } 1 \text { plant, kg }\end{array}$} \\
\hline & & & & $\begin{array}{c}\text { full and } \\
\text { blank } \\
\text { degrees of } \\
\text { maturity }\end{array}$ & $\begin{array}{c}\text { milk } \\
\text { degree } \\
\text { of } \\
\text { maturity }\end{array}$ \\
\hline Contro, water & 04.05 . & 1961 & 16 & 0,79 & 0,29 \\
\hline $\begin{array}{l}\text { Atlante }(0,001 \% \\
\text { solution) }\end{array}$ & 03.05 . & 1977 & 19 & 0,88 & 0,35 \\
\hline
\end{tabular}




\begin{tabular}{|l|l|l|l|l|l|}
\hline $\begin{array}{l}\text { Atlante }(0,005 \% \\
\text { solution) }\end{array}$ & 02.05. & 1989 & 21 & 0,97 & 0,39 \\
\hline LSD $_{05}$ & & & & 0,12 & \\
\hline
\end{tabular}

\section{Discussion}

According to the results of a laboratory assessment of the physiologically active substance effect, it was found that Atlante Plus had a stimulating effect in the 2 nd and 3 rd versions of the experiment. Preliminary soaking of seeds in solutions of various concentrations have shown that variants of the experiment with $0.003 \%$ and $0.005 \%$ concentrations of the drug Atlante Plus have proved to be a stimulator of the metabolic process in the cells of solanum lycopersicum L seeds. Laboratory germination in this experiment variants of solanum lycopersicum L seeds ranged from 93.4-95.9\%, and germination energy - 90.6-92.4\%.

The studied drug did not have an inhibitory effect on the metabolic processes in the cells of solanum lycopersicum L seeds.

In the control version of the experiment, the dates of the single and mass shoots appearance occurred later than all other options. In the laboratory seed germination was $91.1 \%$, germination energy $86.9 \%$.

The $0.001 \%$ concentration of the drug Atlante Plus accelerated the growth processes in the seeds. Despite the fact that single and mass germination of solanum lycopersicum L seeds appeared at the same time as the seeds of the control variant, laboratory germination in this experiment was more than controlled by $2.52 \%$, germination energy - by $4.25 \%$. The best indicators of the solanum lycopersicum L. seeds sowing qualities were in the third variant of the experiment, when using the solution of the drug in the concentration of $0.005 \%$. Despite the fact that the second version of the experiment was superior to the control version in terms of indicators, the germination energy and the solanum lycopersicum L seeds laboratory germination were good and amounted to 95.9 and $92.4 \%$.

In all variants of the experiment, the best results in germination energy and seed germination were shown by the preparation Atlante Plus $(0.005 \%)$. We recommend using this concentration of the drug as growth regulator to increase the solanum lycopersicum $\mathrm{L}$ seeds sowing qualities as the most optimal one.

Plants of solanum lycopersicum L. seedlings of the control variant were delayed with the entry into the phenological phases by 1-3 days compared to other variants of the experiment. In seedlings obtained by soaking seeds in a $0.005 \%$ drug solution the earlier onset periods of the characterized phenological phases (the appearance of seedlings, the first real leaf and 2-3 leaves) were noted.

The use of Atlante Plus for pre-sowing preparation of seeds has significantly increased their sowing qualities. The use of the drug in a concentration of $0.005 \%$ resulted in higher indicators of germination energy (96.5\%) and laboratory germination (96.5\%).

From the data presented in the Table 2, it follows that the concentration of the drug Atlante Plus studied by us had a different effect on the growth of solanum lycopersicum L. seedlings, which was reflected in the habitus indixes. In the solanum lycopersicum L. seedlings the "Leaf surface area" indicator was increased by $0.001 \%$ concentration of the preparation ( 2 variant of the experiment) by $16 \mathrm{~cm}^{2}$ or by $0.8 \%$, compared with the control. Leaf feeding of solanum lycopersicum L plants with the $0.005 \%$ drug concentration (3 variant of the experiment) contributed to an increase in the plants leaf area of by $28 \mathrm{~cm} 2$ or $1,43 \%$, compared with the control and by $12 \mathrm{~cm} 2(0,6 \%)$, compared with the second variant of the experiment. During the period of growing seedlings in the greenhouse 2.8 to 4.3 real leaves were formed on the plants. Solanum lycopersicum L. plants in the $3 \mathrm{rd}$ experiment variant $\mathrm{s}$ had 4 real leaves on average, whereas in the 2 nd variant of the 
experiment, the plants had 3.3 real leaves on average. The lowest foliage was in the plants of the control variant -2.8 real leaves per plant on average.

The height of the solanum lycopersicum L. seedlings varied according to the experiment variants depending on the drug concentration - from 6.4 to $18.6 \mathrm{~cm}$. Increase to control, depending on the drug concentration was $0.1-8.6 \mathrm{~cm}$ or $1.6-86.0 \%$. Tomato plants were more developed in the $3 \mathrm{rd}$ experiment variant, where the concentration of the drug was $0.005 \%$.

In the summer period of the year, at the air temperature of over $30{ }^{\circ} \mathrm{C}$ (and more than 45 ${ }^{\circ} \mathrm{C}$ ) and solar insolation, the appearance of "sunburn" is observed on the fruits of solanum lycopersicum L., and the fall of flowers and fruits - on plants. In this regard, the presence of a powerful leaf apparatus in solanum lycopersicum L. plants is very important. In addition, the assimilation surface determines the productivity of photosynthesis and the potential yield of fruits. For this reason, the notion of "foliage" is of great importance for the evaluation of the studied drug [4, 6-7].

Biometric observations have shown the effectiveness of the drug on vegetating solanum lycopersicum L. The results of the research have demonstrated that the drug Atlante Plus of $0.005 \%$ concentration, had a significant effect on the plants growth during their vegetation period when carrying out leaf and root fertilizing ( 3 version of the experiment). Plants treated with a $0.005 \%$ solution of the drug Atlante Plus formed the largest leaf surface area $-1989 \mathrm{~cm}^{2}(1.5 \%$ higher than the control). This indicator was slightly lower when using the drug at a concentration of $0.001 \%$ (on average, $1977 \mathrm{~cm}^{2}$ ). The plants of the control variant were distinguished by the smallest leaf area in the experiment $-1961 \mathrm{~cm}^{2}$.

The productivity of solanum lycopersicum L. plants consists of the number of fruits and their weight.

The number of fruits in the experimental plants was in the range of $16-21$ pcs., while their total weight ranged from 0.79 to $0.97 \mathrm{~kg}$.

Spraying with the preparation Atlante Plus in the concentration of $0.005 \%$ increased the indicator "Fruit weight per plant" by $0.09 \mathrm{~kg}(10.2 \%)$ compared with the second variant indicators of the experiment and by $0.18 \mathrm{~kg}(22.8 \%)$ compared with the control.

The average weight of tomato fruits of the studied variants in the full maturity degree varied in the range of 75.3-78.7 $\mathrm{g}$ with a fruit diameter of 3.75-3.97 cm (Fig. 2).

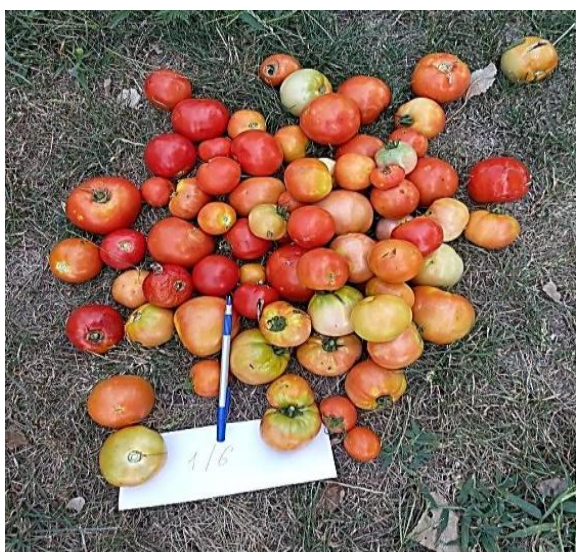

Control version of the experience.

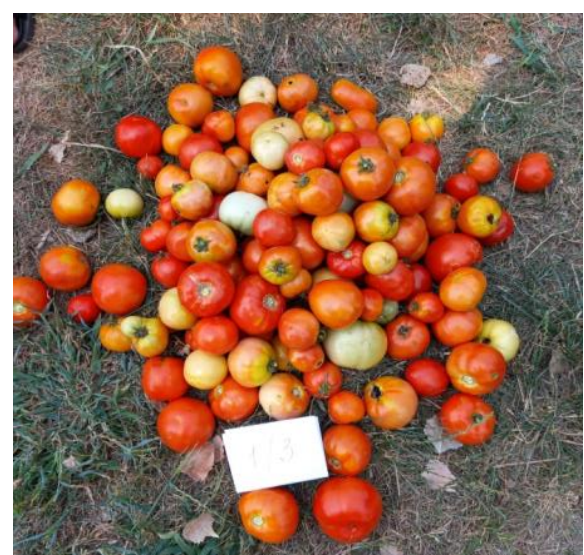

The third variant of the experiment is the treatment of plants with a solution of the drug Atlante Plus in a concentration of $0.005 \%$.

Fig. 1. Tomato fruits from experimental plants, 2021. 
The lowest morpho-biometric indicators of solanum lycopersicum L. fruit production were noted in the variant without treatment of plantings with a physiologically active substance, the highest - with spraying of plants with a $0.005 \%$ solution of the drug Atlante Plus.

Leaf feedings with $0.001 \%$ concentration of the drug Atlante Plus contributed to an increase in the fruits number on solanum lycopersicum L. plants, by 3 pcs. $(18,7 \%)$ on average in comparison with the control variants of the experiment.

The plants of the third variant of the experiment were more productive. Leaf feedings with the drug concentration of $0.005 \%$ contributed to an increase in the number of fruits on the plant by 5 pcs. on average and the weight of fruits on the 1 st plant by $180 \mathrm{~g}(23 \%)$.

\section{Conclusion}

Soaking solanum lycopersicum L. seeds in the solution of Atlante Plus in-creased their germination energy and laboratory germination, respectively, to 90.6-92.4\% and 93.4-95.9 $\%$ and somewhat accelerated the intensity of growth processes in seedlings.

The effectiveness of spraying vegetating plants with solanum lycopersicum L. during the budding phase with the physiologically active substance Atlante Plus confirms the increase in the leaf surface area of plants, the number and weight of fruits. The highest leaf area indicators $\left(1989 \mathrm{~cm}^{2}\right)$ and the productivity of one plant $(0.97 \mathrm{~kg})$ were obtained by spraying solanum lycopersicum L. plants with a $0.005 \%$ solution of the drug.

\section{References}

1. V. Strezov, A. Evans, T.J. Evans, Sustainable development, 25 (2017)

2. T.M. Polushkina, Problems of management theory and practice, 3 (2016)

3. A.V. Peshkova, Int. Agricult. J., 1 (2012)

4. F.Sh. Shaikhutdinov, I.M. Serzhanov, M.F. Amirov, A.R. Valiev, R.M. Nizamov, IOP Conf. Series: Earth and Environmental Science, 341 (2019)

5. J. Hallmann, A. Quadt-Hallmann, W.F. Mahaffee, J. W. Kloepper, Can. J. Microbiol., 43 (1997)

6. D.N. Prianishnikov, Selected Works, 3 (Moscow, 1952)

7. D.N. Prianishnikov, Selected Works, 1 (Moscow, 1965)

8. J. Rochard, C. Herbin, V. Lempereur, BIO Web of Conf., 7 (2016)

9. T.M. Polushkina, E.G. Kovalenko, Yu.A. Akimova, S.A. Kochetkova, J. of Environm. Managem. and Tourism, 8 (2017)

10. V.A. Isaychev, N.N. Andreev, V.G. Polovinkin, S.V. Antonova, Research Journal of Pharmaceutical, Biological and Chemical Sciences, 8, 2 (2017)

11. P. Calvo, L. Nelson, J.W. Kloepper, Plant and Soil, 383 (2014)

12. B.A. Dospekhov, Methodology of field experience (with the basics of statistical processing of research results) (Kolos, Moscow, 1985) 